\title{
Complete chloroplast genome of the orchid Cattleya crispata (Orchidaceae:Laeliinae), a Neotropical rupiculous species
}

\section{Violeta da Rocha Perini, Bruno Leles, Carolina Furtado \& Francisco Prosdocimi}

To cite this article: Violeta da Rocha Perini, Bruno Leles, Carolina Furtado \& Francisco Prosdocimi (2016) Complete chloroplast genome of the orchid Cattleya crispata (Orchidaceae:Laeliinae), a Neotropical rupiculous species, Mitochondrial DNA Part A, 27:6, 4075-4077, DOI: 10.3109/19401736.2014.1003850

To link to this article: https://doi.org/10.3109/19401736.2014.1003850

\section{曲 Published online: 20 Jan 2015.}

Submit your article to this journal

Џ Article views: 114

View Crossmark data ¿ 


\title{
Complete chloroplast genome of the orchid Cattleya crispata (Orchidaceae:Laeliinae), a Neotropical rupiculous species
}

\author{
Violeta da Rocha Perini ${ }^{1,2}$, Bruno Leles ${ }^{3}$, Carolina Furtado ${ }^{4}$, and Francisco Prosdocimi ${ }^{1}$ \\ 'Laboratório de Genômica e Biodiversidade, Instituto de Bioquímica Médica Leopoldo de Meis, Universidade Federal do Rio de Janeiro, Rio de \\ Janeiro, Brazil, ${ }^{2}$ Myleus Biotechnology, Belo Horizonte, Brazil, ${ }^{3}$ Departamento de Ecologia, Universidade Estadual Paulista, Rio Claro, São Paulo, and \\ ${ }^{4}$ Division of Genetics, Instituto Nacional do Câncer, Rio de Janeiro, Brazil
}

\begin{abstract}
A partial genome dataset was sequenced for the orchid Cattleya crispata using both Illumina and 454 technologies. The chloroplast genome was assembled using iterative runs of MIRA software that yielded a circular molecule with 148,343 bp in length and deposited in GenBank database (Accession Number KP168671). The plastid genome conserved the quadripartite structure present in most Orchidaceae chloroplasts and was composed by 79 protein-coding genes, 39 tRNAs and 8 rRNAs. Genome structure, gene order and orientation were similar to previously described chloroplasts for Cymbidium orchids, differing in gene order for pet $\mathrm{N}$ and psbM genes. Data described here contain the first report of a complete chloroplast for the Neotropical subtribe Laeliinae and may contribute to improve the phylogenetic resolution and allow the development of new molecular markers for population genetic studies of orchids.
\end{abstract}

\section{Keywords}

Espinhaço, next-generation-sequencing, orchid, plastid genome, rock outcrop

\section{History}

Received 24 November 2014

Accepted 5 December 2014

Published online 20 January 2015
Orchidaceae is one of the largest families of flowering plants containing about 850 genera and 20,000 species, also being highly diverse in terms of ecology and morphology (Chase, 2005; Dressler, 1990). The fast and extensive diversification patterns observed in orchids impose a challenge for taxonomists that use plastidial markers such as barcodes to identify and study the clade phylogeny (Cameron et al., 1999; van den Berg et al., 2005, 2009). However, the data representation of chloroplast genomes in orchids (about a dozen) is very small in face of the clade diversity. Here we present the complete chloroplast genome of the rupiculous species Cattleya crispata, the first plastid genome of the Neotropical subtribe Laeliinae. This taxon is confined to high-altitude mountains of Espinhaço Range Region in Southeastern Brazil and is considered endangered (Mendonça \& Lins, 2007).

A specimen of $C$. crispata was collected in the Iron Quadrangle region. Genomic DNA was extracted from leaf tissue following the protocol described by Doyle \& Doyle (1987). Partial genome sequencing of $C$. crispata generated $932 \mathrm{Mb}$ of DNA sequences using Illumina HiSeq and $574 \mathrm{Mb}$ using 454 pyrosequencing. In order to select candidate reads encoding chloroplast sequence, we run a bowtie2 (Langmead \& Salzberg, 2012) alignment amongst our dataset into a database created with five complete chloroplast genomes downloaded from NCBI (NC_008591, NC_014056, NC_014874, NC_016471,

Correspondence: Bruno Leles, Departamento de Ecologia, Universidade Estadual Paulista, Rio Claro, São Paulo. E-mail: brunopleles@gmail.com
NC_018114). Candidate chloroplast reads were input into a de novo assembly using MIRA software (Chevreux et al., 1999). MIRA was unable to assemble the whole chloroplast into a single scaffold, thus we merged two scaffolds to produce a candidate sequence that was used as input for a reference-based assembly, allowing the production of the complete sequence described. The complete circularized genome contained 148,343 bp in length and was deposited in GenBank (Accession Number KP168671). The plastid genome conserved the quadripartite structure, composed of two copies of a inverted region (IR), a large single copy region (LSC) and a small single copy (SSC), following the typical pattern observed in photosynthetic orchids (Jheng et al., 2012; Luo et al., 2014). Genome coverage checked using Tablet software (Milne et al., 2013) resulted in $\sim 150 \times$ uniformly distributed reads along the genome, with the exception of a single region between the genes clpP and psbB that showed low coverage. Automatic annotation was performed using DOGMA (Wyman et al., 2004), followed by careful manual curation using Artemis (Carver et al., 2012). Transfer RNA predictions were checked with tRNAscan-SE (Lowe \& Eddy, 1997). The gene content composed of 79 protein-coding genes, 39 tRNAs and 8 rRNAs (Figure 1). Genome structure, gene order and orientation were similar to the chloroplast of the orchid genus Cymbidium, differing in gene order for two genes (petN and psbM) (Yang et al., 2013). The complete chloroplast genome of $C$. crispata may benefit further phylogenetic, phylogeographic, population genetic and species delimitation studies, which are essential for the ongoing conservation efforts to manage this endangered species and also contribute for better understanding of Neotropical orchid evolution. 


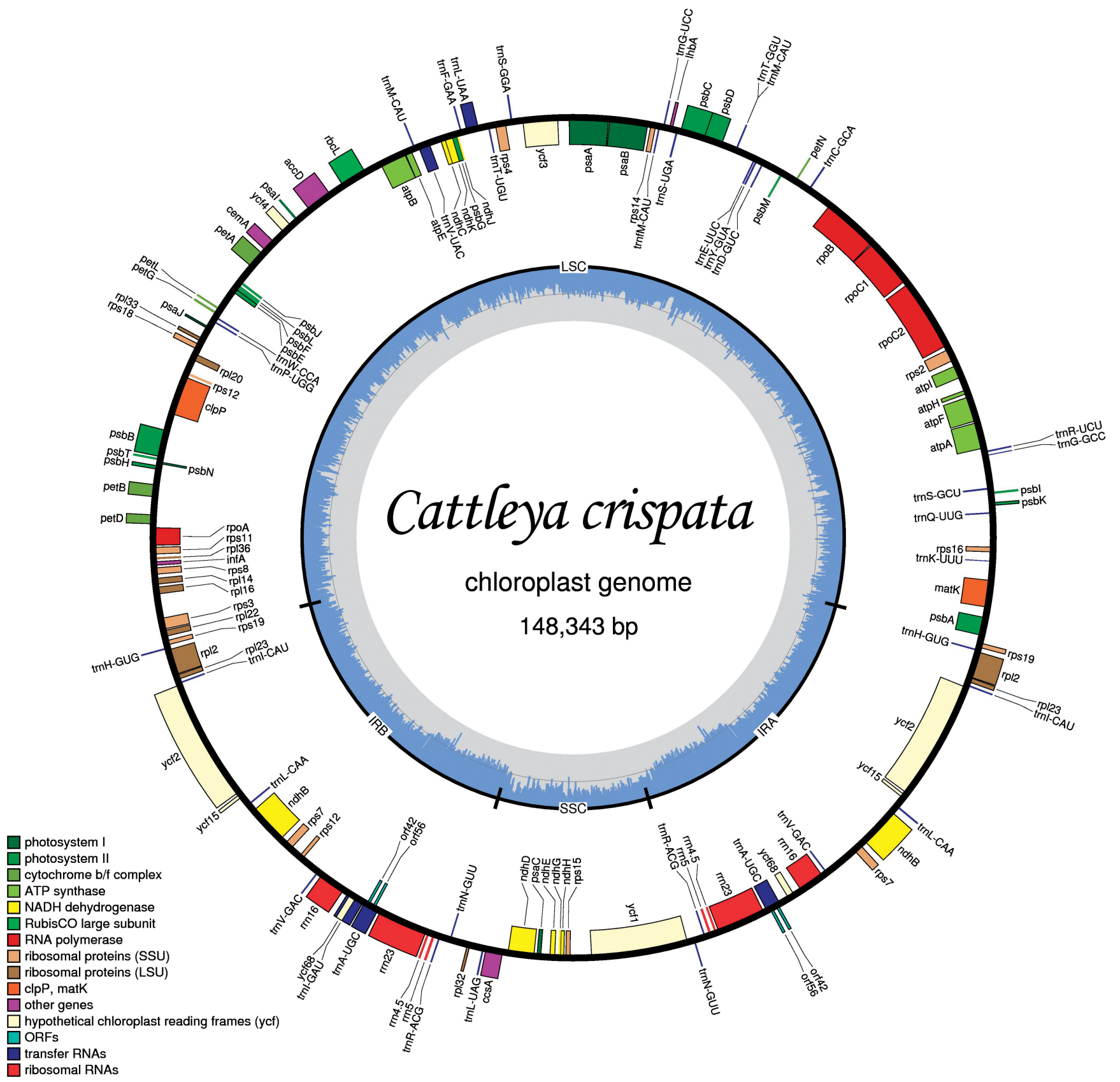

Figure 1. Genome map of the Cattleya crispata chloroplast. Genes shown outside of the outer circle are transcribed clockwise, whereas those shown inside are transcribed counterclockwise. Genes belonging to different functional groups are color coded. Area dashed blue in the inner circle indicates GC content while the gray corresponds to AT content of the genome.

\section{Declaration of interest}

This project was supported by Brazilian funding agencies FAPERJ, FAPEMIG and CNPq. We acknowledged a FAPEMIG MSc scholarship and funding from Fundação Boticário to BPL. The authors alone are responsible for the content and writing of the paper.

\section{References}

Cameron KM, Chase MW, Whitten WM, Kores PJ, Jarrell DC, Albert VA, Yukawa T, et al. (1999). A phylogenetic analysis of the Orchidaceae: Evidence from rbcL nucleotide. Am J Bot 86: 208-24.

Carver T, Harris SR, Berriman M, Parkhill J, McQuillan JA. (2012). Artemis: An integrated platform for visualization and analysis of highthroughput sequence-based experimental data. Bioinformatics 28: 464-9.

Chase MW. (2005). Classification of Orchidaceae in the age of DNA data. Curtis's Bot Mag 22:2-7.
Chevreux B, Wetter T, Suhai S. (1999). Genome sequence assembly using trace signals and additional sequence information. Comput Sci Biol: Proc German Conf Bioinform 99:45-56.

Doyle JJ, Doyle JL. (1987). A rapid DNA isolation procedure for small quantities of fresh leaf tissue. Phytochem Bull 19:11-15.

Dressler RL. (1990). The Orchids: Natural history and classification. Cambridge, MA: Harvard University Press.

Jheng C-F, Chen T-C, Lin J-Y, Chen T-C, Wu W-L, Chang C-C. (2012). The comparative chloroplast genomic analysis of photosynthetic orchids and developing DNA markers to distinguish Phalaenopsis orchids. Plant Sci 190:62-73.

Lowe TM, Eddy SR (1997). tRNAscan-SE: A program for improved detection of transfer RNA genes in genomic sequence. Nucleic Acids Res 25:955-64.

Langmead B, Salzberg S. (2012). Fast gapped-read alignment with Bowtie 2. Nat Methods 9:357-9.

Luo J, Hou B-W, Niu Z-T, Liu W, Xue Q-Y, Ding X-Y. (2014). Comparative chloroplast genomes of photosynthetic orchids: Insights into evolution of the orchidaceae and development of molecular markers for phylogenetic applications. PloS One 9:e99016. 
Mendonça MP, Lins LV. (2007). Revisão das listas das espécies da flora e da fauna Ameaçadas de extinção do estado de minas gerais. Belo Horizonte, MG, Brasil: Fundação Biodiversitas.

Milne I, Stephen G, Bayer M, Cock PJ, Pritchard L, Cardle L, Shaw PD, Marshall D. (2013). Using tablet for visual exploration of secondgeneration sequencing data. Brief Bioinform 14:193-202.

Van den Berg C, Goldman DH, Freudenstein JV, Pridgeon AM, Cameron KM, Chase MW. (2005). An overview of the phylogenetic relationships within Epidendroideae inferred from multiple DNA regions and recircumscription of Epidendreae and Arethuseae (Orchidaceae). Am J Bot 92:613-24.
Van den Berg C, Higgins WE, Dressler RL, Whitten WM, Soto-Arenas M, Chase MW. (2009). A phylogenetic study of Laeliinae (Orchidaceae) based on combined nuclear and plastid DNA sequences. Ann Bot 104:417-30.

Wyman SK, Jansen RK, Boore JL. (2004). Automatic annotation of organellar genomes with DOGMA. Bioinformatics 20:3252-5.

Yang J-B, Tang M, Li H-T, Zhang Z-R, Li D-Z. (2013). Complete chloroplast genome of the genus Cymbidium: Lights into the species identification, phylogenetic implications and population genetic analyses. BMC Evol Biol 13:84. 